\title{
Critical role of bevacizumab scheduling in combination with pre- surgical chemo-radiotherapy in MRI-defined high-risk locally advanced rectal cancer: Results of the BRANCH trial
}

\author{
Antonio Avallone ${ }^{1}$, Biagio Pecori ${ }^{2}$, Franco Bianco ${ }^{3}$, Luigi Aloj ${ }^{4}$, Fabiana Tatangelo ${ }^{5}$, \\ Carmela Romano ${ }^{1}$, Vincenza Granata ${ }^{6}$, Pietro Marone $^{7}$, Alessandra Leone ${ }^{8}$, Gerardo \\ Botti $^{5}$, Antonella Petrillo ${ }^{6}$, Corradina Caracò ${ }^{4}$, Vincenzo R. Iaffaioli ${ }^{1}$, Paolo Muto ${ }^{2}$, \\ Giovanni Romano ${ }^{3}$, Pasquale Comella ${ }^{1}$, Alfredo Budillon ${ }^{8}$, Paolo Delrio ${ }^{9}$ \\ ${ }^{1}$ Gastrointestinal Medical Oncology Unit, Istituto Nazionale per lo Studio e la Cura dei Tumori "Fondazione Giovanni Pascale" - \\ IRCCS, 80131, Napoli, Italy \\ ${ }^{2}$ Radiotherapy Unit, Istituto Nazionale per lo Studio e la Cura dei Tumori "Fondazione Giovanni Pascale" - IRCCS, 80131, \\ Napoli, Italy \\ ${ }^{3}$ Gastrointestinal Surgery, Istituto Nazionale per lo Studio e la Cura dei Tumori "Fondazione Giovanni Pascale" - IRCCS, \\ 80131, Napoli, Italy \\ ${ }^{4}$ Nuclear Medicine Unit, Istituto Nazionale per lo Studio e la Cura dei Tumori "Fondazione Giovanni Pascale" - IRCCS, 80131, \\ Napoli, Italy \\ ${ }^{5}$ Pathology Unit, Istituto Nazionale per lo Studio e la Cura dei Tumori "Fondazione Giovanni Pascale" - IRCCS, 80131, Napoli, \\ Italy \\ ${ }^{6}$ Radiology Unit, Istituto Nazionale per lo Studio e la Cura dei Tumori "Fondazione Giovanni Pascale" - IRCCS, 80131, Napoli, \\ Italy \\ ${ }^{7}$ Endoscopy Unit, Istituto Nazionale per lo Studio e la Cura dei Tumori "Fondazione Giovanni Pascale" - IRCCS, 80131, \\ Napoli, Italy \\ ${ }^{8}$ Experimental Pharmacology Unit, Istituto Nazionale per lo Studio e la Cura dei Tumori "Fondazione Giovanni Pascale" - \\ IRCCS, 80131, Napoli, Italy \\ ${ }^{9}$ Colorectal Surgery Unit, Istituto Nazionale per lo Studio e la Cura dei Tumori "Fondazione Giovanni Pascale" - IRCCS, 80131, \\ Napoli, Italy \\ Correspondence to: \\ Antonio Avallone, e-mail: a.avallone@istitutotumori.na.it \\ Keywords: locally advanced rectal cancer, bevacizumab, preoperative chemo-radiotherapy, adjuvant chemotherapy, vessel \\ normalization \\ Received: May 17, $2015 \quad$ Accepted: July 17, $2015 \quad$ Published: July 30, 2015
}

\section{ABSTRACT}

Background: We have previously shown that an intensified preoperative regimen including oxaliplatin plus raltitrexed and 5-fluorouracil/folinic acid (OXATOM/ FUFA) during preoperative pelvic radiotherapy produced promising results in locally advanced rectal cancer (LARC). Preclinical evidence suggests that the scheduling of bevacizumab may be crucial to optimize its combination with chemo-radiotherapy.

Patients and methods: This non-randomized, non-comparative, phase II study was conducted in MRI-defined high-risk LARC. Patients received three biweekly cycles of OXATOM/FUFA during RT. Bevacizumab was given 2 weeks before the start of chemoradiotherapy, and on the same day of chemotherapy for 3 cycles (concomitant-schedule A) or 4 days prior to the first and second cycle of chemotherapy (sequential-schedule B). Primary end point was pathological complete tumor regression (TRG1) rate.

Results: The accrual for the concomitant-schedule was early terminated because the number of TRG1 ( 2 out of 16 patients) was statistically inconsistent with the hypothesis of activity (30\%) to be tested. Conversely, the endpoint was reached with the sequential-schedule and the final TRG1 rate among 46 enrolled patients was $50 \%(95 \%$ CI $35 \%-65 \%)$. Neutropenia was the most common grade 


\begin{abstract}
$\geq 3$ toxicity with both schedules, but it was less pronounced with the sequential than concomitant-schedule ( $30 \%$ vs. $44 \%)$. Postoperative complications occurred in $8 / 15(53 \%)$ and $13 / 46(28 \%)$ patients in schedule A and B, respectively. At 5 year follow-up the probability of PFS and OS was $80 \%$ (95\%CI, $66 \%-89 \%$ ) and $85 \%$ (95\%CI, 69\%-93\%), respectively, for the sequential-schedule. Conclusions: These results highlights the relevance of bevacizumab scheduling to optimize its combination with preoperative chemo-radiotherapy in the management of LARC.
\end{abstract}

\section{INTRODUCTION}

The evolution of preoperative multimodality treatment has improved the local control of locally advanced rectal cancer (LARC). Distant metastases, however, remain a clinical challenge and more effective systemic approaches are needed [1]. LARC comprises a heterogeneous group of tumors in which outcomes vary significantly depending on prognostic factors, namely $\mathrm{T}$ and $\mathrm{N}$ stage, involvement of the circumferential resection margin (CRM) and low-lying location [2]. The highresolution magnetic resonance imaging (MRI) allows the preoperative identification of high-risk features, enabling patient selection for risk-adapted treatment [2]. In such high-risk LARC patients we have recently reported promising results from a phase-2 trial based on an original intensified preoperative chemotherapy (CT) regimen including oxaliplatin plus raltitrexed and 5-fluorouracil modulated by folinic acid (OXATOM/ FUFA) at full systemic doses, during preoperative pelvic radiotherapy (RT). High rates of complete $(40 \%)$ and near-complete $(25 \%)$ pathologic tumor regression were observed, with a 5-year freedom from recurrence of $80 \%$ and a 5 -year overall survival (OS) of $87 \%$ [3]. On the basis of preclinical and clinical data the integration of bevacizumab into fluoropyrimidines-based chemoradiotherapy (CRT) has been extensively investigated in phase II studies [4, 5]. However, results overall have been modest and concerns regarding increased surgical morbidity have been raised [6]. Several evidences suggest that the chemo-sensitizing activity exerted by anti-VEGF agents depends on the so-called "vessel to normalization, in which a reduction of tumor vessel abnormalities results in more efficient delivery of drugs and oxygen to cancer cells [7]. Although genetic studies have shown prolonged maintenance of vascular normalization [8], in preclinical models pharmacological VEGF inhibitors induced a transient vessel normalization, occurring a few days after anti-VEGF administration $[9,10]$. Therefore, rescheduling of bevacizumab relative to $\mathrm{CT}$ and RT could be of critical importance to optimize the efficacy of the combination treatment. On these basis we conducted a phase-2 study in MRI-defined high-risk LARC patients, in order to evaluate the addition of bevacizumab to OXATOM/FUFA during preoperative RT.
A concomitant schedule, in which bevacizumab was administered concurrentlyy to CT, was initially evaluated. Thereafter, a sequential schedule, in which bevacizumab was given 4 days before $\mathrm{CT}$, was also evaluated in order to explore the clinical relevance of "vessel normalization".

The primary endpoint of the study was the rate of TRG1. However, considering the controversial prognostic value of short term pathological end points and the paucity of data on long-term outcomes of LARC patients, we also report on these findings with a prolonged follow-up.

\section{RESULTS}

\section{Patient characteristics and treatment}

Between December 2006 and July 201116 patients were enrolled in schedule A (concomitant) and 46 in schedule B (sequential). Demographic and baseline disease characteristics by treatment schedule are shown in Table 1. Most patients had more than one high-risk factor. Among patients with radial margin $\leq 5 \mathrm{~mm}$ from the mesorectal fascia (MRF), evaluated by MRI and considered to have potentially positive CRM, 4/13 (31\%) in schedule A and 29/35 (83\%) in schedule B showed tumor location within $2 \mathrm{~mm}$ of the MRF. All T3N0-1 tumors had a potentially positive CRM and/or extramural extension $\geq 5 \mathrm{~mm}$.

All patients in schedule A and all but 1 patient in schedule B received the planned dose of RT. The radiation treatment was completed in a median of 39 (range, 35-45) and 36 (range, 33-49) days in schedule $\mathrm{A}$ and $\mathrm{B}$, respectively. One patient in each group did not receive the third cycle of chemotherapy due to severe and persistent neutropenia and diarrhea. Overall, the median relative dose intensities of cytotoxic drugs were: $87 \%$ and $97 \%$ for oxaliplatin, $87 \%$ and $97 \%$ for raltitrexed, $83 \%$ and $92 \%$ for $5-\mathrm{FU}, 94 \%$ and $100 \%$ for bevacizumab, in schedule A and B, respectively. The only patient with metastatic disease enrolled in schedule A and 4 out of 7 metastatic patients in schedule $\mathrm{B}$ received two additional cycles of chemotherapy after the end of RT. One patient in schedule A with a complete clinical response refused surgery. The median interval between the end of RT and TME was 9 weeks for both schedule A (range, 7-14) and B (range, 7-15). 
Table 1: Baseline patient and tumor characteristics

\begin{tabular}{|c|c|c|}
\hline Characteristics & $\begin{array}{c}\text { Schedule A } \\
n=16(\% \text { of total })\end{array}$ & $\begin{array}{c}\text { Schedule B } \\
n=46(\% \text { of total })\end{array}$ \\
\hline \multicolumn{3}{|l|}{ Gender } \\
\hline Male/Female & $9(56) / 7(44)$ & $28(61) / 18(39)$ \\
\hline Median age (range) & $55(48-69)$ & $61(43-74)$ \\
\hline \multicolumn{3}{|l|}{ ECOG Performance status } \\
\hline 0 & $8(50)$ & $22(48)$ \\
\hline $1 / 2$ & $7(44) / 1(6)$ & $13(50) / 1(2)$ \\
\hline \multicolumn{3}{|l|}{ Clinical staging } \\
\hline T3N0 & $3(19)$ & $1(2)$ \\
\hline T3N1/T4N0 & $7(44) / 1(6)$ & $14(30) / 1(2)$ \\
\hline T3N2/T4N1-2 & $2(12) / 2(12)$ & $22(48) / 1(2)$ \\
\hline T3N0M1/T3N1M1 & - & $1(2) / 2(4)$ \\
\hline T3N2M1/T4N2M1 & $1(6) / 0$ & $3(7) / 1(2)$ \\
\hline \multicolumn{3}{|l|}{ Distance from the anal verge } \\
\hline$\leq 5 \mathrm{~cm}$ (low-lying tumor) & $9(56)$ & $25(54)$ \\
\hline$>5 \mathrm{~cm}$ (mid/upper tumor) & $7(44)$ & $21(46)$ \\
\hline \multicolumn{3}{|c|}{ Distance of Mesorectal Fascia (MRF) } \\
\hline$\leq 5 \mathrm{~mm}$ & $13(81)$ & $35(76)$ \\
\hline$>5 \mathrm{~mm}$ & $2(12)$ & $8(18)$ \\
\hline Not evaluated* & $1(6)$ & $3(7)$ \\
\hline \multicolumn{3}{|l|}{ Baseline CEA serum level } \\
\hline$\leq 5 \mathrm{UI} / \mathrm{L}$ & $10(62)$ & $28(61)$ \\
\hline$>5 \mathrm{UI} / \mathrm{L}$ & $6(37)$ & $18(39)$ \\
\hline
\end{tabular}

*MRI not performed, metal prosthesis.

\section{Outcome}

Surgical outcome and pathological tumor responses are summarized in Table 2. Notably, the incomplete resection in schedule $\mathrm{B}$ pertained only to metastatic disease. There were no instances of disease progression during treatment.

According to the preplanned first-stage analysis, the accrual for schedule A was terminated since only 2 TRG1 responses were identified. Conversely, in schedule B, 8/15 patients showed a TRG1 in the first stage and 23/46 (50\%; $95 \%$ CI, 35\%-65\%) in the second stage. Importantly, TRG1 status was achieved independently of the pre-treatment clinical stage (Table 3 ). In addition, 15 patients (33\%; 95\% CI, $21 \%-47 \%$ ) obtained a near complete tumor regression with schedule B (TRG2, Table 2). Pathological tumor downstaging occurred in 39/46 (85\%) patients (Table 3).
A median of 32 (range, 19-62) and 27 (range, 12-108) lymph nodes per patient were harvested in schedule $\mathrm{A}$ and $\mathrm{B}$, respectively. Pathological nodal downstaging occurred in 32/43 (74\%) patients (Table 3 ). In schedule B, 4 patients with TRG1 ( 2 with baseline metastatic disease) revealed pathological nodal involvement. Overall pCR rate was $41 \%$ and 30/46 (65\%) patients had a ypT0-2N0 status (Table 2).

As provided by the selective adjuvant policy adopted in the study, 5 patients in schedule A and 13/16 patients in schedule B (3 patients with baseline metastatic disease and R0/R1 resection refused further treatment), received post-operative FOLFOX4 after a median of 7 weeks (schedule A, range: 7-9; schedule B, range: 4-15) from surgery. In schedule A, with a median follow-up at the time of analysis of 91 (range, 84-96) months, 2 patients had distant recurrence, 3 patients had both local and distant recurrence and 5 patients died. 
Table 2: Surgical outcomes and pathological tumor response

\begin{tabular}{|c|c|c|}
\hline Parameters & $\begin{array}{l}\text { Schedule } A^{\circ}(n=16) \\
n(\% ; 95 \% \mathrm{CI})\end{array}$ & $\begin{array}{l}\text { Schedule B }(n=46) \\
\quad n(\% ; 95 \% \text { CI })\end{array}$ \\
\hline \multicolumn{3}{|l|}{ Surgery type } \\
\hline Anterior resection & $13(81 ; 57-93)$ & $41(89 ; 77-95)$ \\
\hline Abdominoperineal resection & $2(12 ; 3-36)$ & $5(11 ; 5-23)$ \\
\hline $\begin{array}{l}\text { Sphincter preservation in patients } \\
\text { with tumor } \leq 5 \mathrm{~cm} \text { from anal verge }\end{array}$ & $5 / 9(56 ; 27-81)$ & $20 / 25(80 ; 61-91)$ \\
\hline \multicolumn{3}{|l|}{ Resection Status } \\
\hline Complete resection (R0) & $13(81 ; 57-93)$ & $43(93 ; 82-98)$ \\
\hline Microscopic residual disease (R1) & $1 *(6 ; 1-28)$ & $1 * *(2 ; 0-11)$ \\
\hline Macroscopic residual disease (R2) & $1 *(6 ; 1-28)$ & $2 * *(4 ; 1-14)$ \\
\hline \multicolumn{3}{|l|}{ ypTypN status } \\
\hline ypT0ypN0 (pCR) & $2(12 ; 3-36)$ & $19(41 ; 28-56)$ \\
\hline урT0-2ypN0 & $8(50 ; 28-72)$ & $30(65 ; 51-77)$ \\
\hline ypN1-2 & $5(31 ; 14-56)$ & $14(30 ; 19-45)$ \\
\hline \multicolumn{3}{|l|}{ Mandard tumor regression grade } \\
\hline TRG1 & $2(12 ; 3-36)$ & $23(50 ; 36-64)$ \\
\hline TRG2 & $8(50 ; 28-72)$ & $15(33 ; 21-47)$ \\
\hline TRG3 & $3(19 ; 7-43)$ & $7(15 ; 7-28)$ \\
\hline TRG4 & $2(12 ; 3-36)$ & $1(2 ; 0-11)$ \\
\hline TRG5 & 0 & 0 \\
\hline
\end{tabular}

${ }^{\circ}$ one patient refused surgery;

* R1 or R2 resection on primary tumor;

** $\mathrm{R} 1$ or $\mathrm{R} 2$ resection on metastatic disease

In schedule B after a median follow up of 54 (range, 41-83) months, $37 / 46(80 \%)$ patients continued to be disease-free. One patient $(\mathrm{ypN}+)$ had a local recurrence, 3 patients (including 1 with early interruption of CRT and $1 \mathrm{ypN}+$ ) had both local and distant recurrences and 2 patients (both ypN+) had distant recurrence. Of note, 4 patients with baseline metastatic disease (3 achieving a TRG1 response) were still disease-free. Six patients died of rectal cancer specific causes. At 5-years follow-up the probability of Progression-free survival (PFS) and OS was $80 \%$ (95\%CI, 66\%-89\%) and, 85\% (95\%CI, 69\%-93\%), respectively, for schedule B (Figure 1).

\section{Safety}

Treatment induced side effects are summarized in Table 4. Toxicity profiles were similar between the two schedules and neutropenia was the most common grade $\geq 3$ adverse event, but it was short lasting and easily managed. Notably, severe neutropenia was less pronounced in schedule B (30\% vs. $44 \%)$. Furthermore, $6 / 14(43 \%)$ episodes of severe neutropenia in schedule
$\mathrm{B}$, as opposed to $1 / 7(14 \%)$ in schedule $\mathrm{A}$, occurred only after the end of CRT, thus not causing treatment delays or dose modifications. No cardiac or thromboembolic events, hemorrhages or perforations were observed.

Postoperative complications occurred in 8/15 (53\%) and 13/46 (28\%) patients in schedule A and B, respectively (Table 5). Re-operation was necessary in 3 patients $(19 \%)$ in schedule A and in 4 patients ( $9 \%$ ) in schedule B. One patient per schedule required a permanent colostomy. There were no deaths correlated with CRT or surgery in either treatment schedules.

Moderate or severe late toxicities were reported in 6/15 (40\%) and 19/46 (41\%) patients in schedule A and B, respectively (Table 5).

\section{DISCUSSION}

The present results support the hypothesis that rescheduling of anti-VEGF treatment relative to CT and RT could be of critical importance to improve the efficacy of combination treatment. The concomitant delivery of 
Table 3: Comparison of baseline staging with pathological findings in schedule B

\begin{tabular}{|c|c|c|c|c|}
\hline & \multicolumn{4}{|c|}{ Tumor Regression Grade (TRG) } \\
\hline & \multicolumn{4}{|c|}{ Schedule B $n=46$} \\
\hline & TRG1 & TRG2 & TRG3 & TRG4 \\
\hline Baseline Staging & $n=23$ & $n=15$ & $n=7$ & $n=1$ \\
\hline $\begin{array}{c}\text { cT3N0 } \\
n=1\end{array}$ & & 1(ypT2N0) & & \\
\hline $\begin{array}{l}\text { cT3N1 } \\
n=14\end{array}$ & $\begin{array}{l}\text { 6(ypT0N0); } \\
1 \text { (урT0N1b) }\end{array}$ & $\begin{array}{l}2(y p T 2 N 0) \\
1(y p T 2 N 1 a)\end{array}$ & $\begin{array}{c}\text { 1(ypT2N0);1(ypT3N0) } \\
\text { 1(ypT2N1a) }\end{array}$ & $1($ урT3N2b) \\
\hline $\begin{array}{l}\text { T4N0 } \\
n=1\end{array}$ & 1(ypT0N0) & & & \\
\hline $\begin{array}{l}\text { cT3N2 } \\
n=22\end{array}$ & $\begin{array}{l}\text { 7(ypT0N0); } \\
1(\text { урT0N1b) }\end{array}$ & $\begin{array}{c}3(\text { урT1N0);3(ypT2N0) } \\
\text { 1(ypT2N1a);2(ypT2N1b) } \\
\text { 1(ypT2N2a)1(ypT3N2a) }\end{array}$ & $\begin{array}{c}\text { 1(ypT1N0);1(ypT3N0) } \\
\text { 1(ypT3N1a) }\end{array}$ & \\
\hline $\begin{array}{c}\text { cT4N1-2 } \\
n=1\end{array}$ & 1(ypT0N0) & & & \\
\hline $\begin{array}{c}\text { cT3N0M1 } \\
n=1\end{array}$ & 1(ypT0N0cM0)* & & & \\
\hline $\begin{array}{c}\text { cT3N1M1 } \\
n=2\end{array}$ & $\begin{array}{l}\text { 1(урT0N0M1) } \\
\text { 1(ypT0N1aM1) }\end{array}$ & & & \\
\hline $\begin{array}{c}\mathrm{cT} 3 \mathrm{~N} 2 \mathrm{M} 1 \\
n=3\end{array}$ & $\begin{array}{l}\text { 1(урT0N0M0) } \\
1(\text { ypT0N2bM0) }\end{array}$ & & 1(ypT2N2aM1) & \\
\hline $\begin{array}{c}\text { cT4N2M1 } \\
n=1\end{array}$ & 1(ypT0N0M1) & & & \\
\hline
\end{tabular}

cTNM = clinical staging; ypTNM = pathological staging after chemoradiotherapy treatment

*clinical complete response of the lung metastases

bevacizumab with the OXATOM/FUFA regimen during RT did not meet the primary endpoint.

With the sequential schedule, on the other hand, the endpoint was reached in both stages of Simon's statistical design and the final TRG1 rate was 50\% (95\% CI, $35 \%-65 \%$ ), slightly better compared to our previous experience with the same regimen without bevacizumab $(40 \%)$ [3]. In addition, a near complete tumor regression was observed in 15 further patients, with an overall rate of TRG1/TRG2 responses of $83 \%$ (95\% CI, $69 \%-91 \%)$, which was higher compared to our previous experience without bevacizumab (65\%) [3]. Moreover, we should also point out that most patients enrolled in the current study had more than one high-risk factor, including 15\% of patients with metastatic disease, who were not included in our previous experience.

Although four patients with TRG1 had pathological nodal involvement, the $41 \%$ pCR rate is still impressive. Notably, these results were observed regardless of pretreatment clinical stage and were reported through a robust pathological analysis, as proven by the elevated median number of lymph nodes retrieved. Additional remarkable findings were the $93 \% \mathrm{R} 0$ resection rate, the $65 \%$ ypT0-2N0 rate, the $80 \%$ sphincter-sparing surgery rate and the clinical or pathological complete response of metastatic sites in 3/7 patients. All this data endorses the efficacy of the sequential bevacizumab schedule with OXATOM/FUFA during RT. The consistency of these findings was corroborated by the long-term outcome of patients.

Indeed, the 80\% 5-year PFS and 85\% 5-year OS indicates a good and durable distant control. These results are particularly relevant considering the poor prognostic features of the enrolled patients.

The selective adjuvant policy adopted in our trial strengthens the value of these findings, minimizing the influence of the adjuvant therapy on long-term outcome. Indeed, postoperative FOLFOX4 was delivered only in a small subgroup of patients. Although there is no general agreement on the benefit of adjuvant chemotherapy after preoperative CRT [11], there is recent compelling evidence supporting the use of a risk-adapted strategy based on pathological findings to select candidates for CT after surgery $[12,13]$. Moreover, recent results of the randomized phase-2 ADORE study in LARC patients suggest that those less responsive to fluoropyrimidinebased CRT may benefit from four months of adjuvant FOLFOX chemotherapy [14]. 

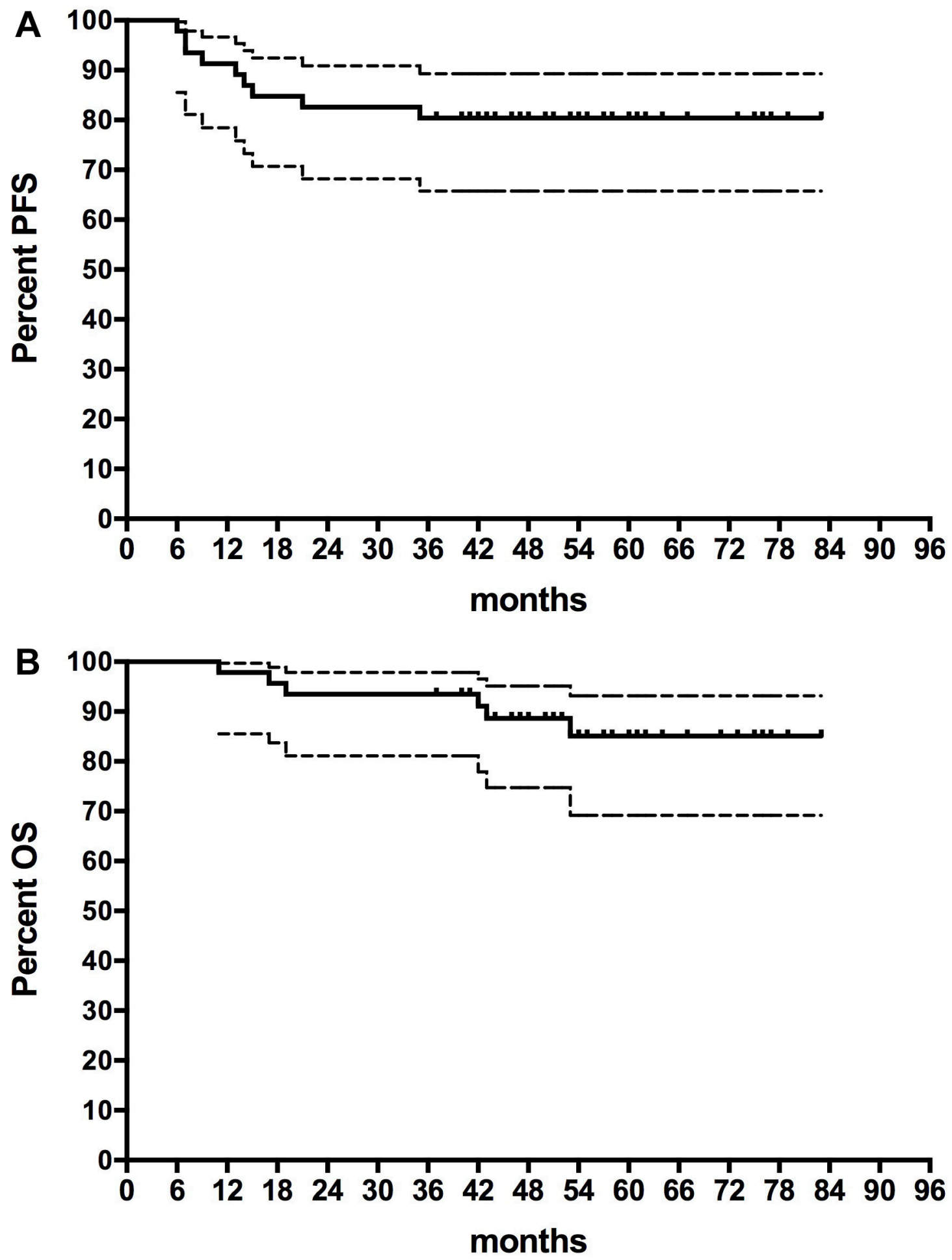

Figure 1: Kaplan-Meier survival curves. Dashed curves represent 95\% CIs. A. Progression-free survival for the schedule B. B. Overall survival for the schedule B.

Although comparisons across studies should be made with caution, our findings are encouraging when compared to results of similar studies employing preoperative treatment on MRI-defined high-risk LARC patients [15]. Only two studies investigating the integration of bevacizumab into preoperative treatment reported a pCR rate $>30 \%$ (Table 6 [16-28]).

Crane and colleagues [18] reported a pCR rate of $32 \%$ and an additional microscopic residual disease rate of $24 \%$ with the administration of capecitabine and 
Table 4: Treatment Related Toxicity

\begin{tabular}{|c|c|c|c|c|c|c|c|c|c|c|c|c|}
\hline \multirow{3}{*}{ Toxicity } & \multicolumn{6}{|c|}{ Schedule A $(n=16)$} & \multicolumn{6}{|c|}{ Schedule B $(n=46)$} \\
\hline & \multicolumn{2}{|c|}{ Grade 1-2 } & \multicolumn{2}{|c|}{ Grade 3-4 } & \multicolumn{2}{|c|}{ Total } & \multicolumn{2}{|c|}{ Grade 1-2 } & \multicolumn{2}{|c|}{ Grade 3-4 } & \multicolumn{2}{|c|}{ Total } \\
\hline & No. & $\%$ & No. & $\%$ & No. & $\%$ & No. & $\%$ & No. & $\%$ & No. & $\%$ \\
\hline Neutropenia & 7 & 44 & 7 & 44 & 14 & 87 & 9 & 20 & 14 & 30 & 23 & 50 \\
\hline Thrombocytopenia & 1 & 6 & 0 & & 1 & 6 & 1 & 2 & 1 & 2 & 2 & 4 \\
\hline Anemia & 0 & & 1 & 6 & 1 & 6 & 6 & 13 & 1 & 2 & 7 & 15 \\
\hline Nausea/vomiting & 7 & 44 & 0 & & 7 & 44 & 22 & 48 & 0 & & 22 & 48 \\
\hline Abdominal pain & 3 & 19 & 0 & & 3 & 19 & 4 & 9 & 0 & & 4 & 9 \\
\hline Diarrhea & 6 & 37 & 1 & 6 & 7 & 43 & 16 & 35 & 3 & 6 & 19 & 41 \\
\hline Stomatitis & 1 & 6 & 0 & & 1 & 6 & 2 & 4 & 0 & & 2 & 4 \\
\hline Proctitis & 4 & 25 & 0 & & 4 & 25 & 14 & 30 & 0 & & 14 & 30 \\
\hline Proteinuria & 3 & 19 & 0 & & 3 & 19 & 4 & 9 & 0 & & 4 & 9 \\
\hline Liver enzymes & 2 & 12 & 0 & & 2 & 12 & 9 & 20 & 1 & 2 & 10 & 22 \\
\hline Skin reactions & 3 & 19 & 0 & & 3 & 19 & 5 & 11 & 0 & & 5 & 11 \\
\hline Asthenia & 4 & 25 & 0 & & 4 & 25 & 10 & 22 & 2 & 4 & 12 & 26 \\
\hline Neuropathy & 2 & 12 & 0 & & 2 & 12 & 6 & 13 & 0 & & 6 & 13 \\
\hline Hypertension & 4 & 25 & 1 & 6 & 5 & 31 & 11 & 24 & 0 & & 11 & 24 \\
\hline Anorexia & 2 & 12 & 0 & & 2 & 12 & 3 & 6 & 2 & 4 & 5 & 10 \\
\hline Rectal tenesmus & 2 & 12 & 0 & & 2 & 12 & 6 & 13 & 0 & & 6 & 13 \\
\hline Cystitis & 2 & 12 & 0 & & 2 & 12 & 4 & 9 & 0 & & 4 & 9 \\
\hline
\end{tabular}

bevacizumab concomitant to preoperative RT. However, patient selection in this study, as with most studies assessing bevacizumab, was not based on MRI criteria (Table 6 [16-28]). Furthermore, PFS (with a shorter follow-up) was markedly lower than in our series [18]. A slightly higher pCR rate of $34 \%$ and an additional nearypCR rate of $36 \%$ were observed in a phase- 2 study, in which patients received induction chemotherapy with 4 cycles of bevacizumab plus XELOX, followed by CRT with concurrent capecitabine and bevacizumab. In this study, MRI selection criteria were used but, unlike in our study, patients with metastatic disease were not included, dose of RT was higher and long-term outcome was not reported [19].

With respect to safety, the combination of bevacizumab with RT and OXATOM/FUFA was well tolerated. Toxicities were manageable and similar to those previously reported with the same CRT regimen without bevacizumab [3]. Neutropenia was the most common toxicity but did not decrease the treatment compliance. Interestingly the incidence of grade $\geq 3$ neutropenia reported for schedule B was lower compared to the same CRT regimen without or with bevacizumab in the concomitant schedule. In line with these results, recent preclinical data shows that the sequential delivery of antiangiogenic drugs followed by chemotherapy yields a lower bone marrow toxicity compared to the concomitant administration [29].

In agreement with some trials evaluating the integration of bevacizumab in preoperative treatment (Table 5), we observed high a rate of surgical complications and re-operation under schedule A, while postoperative complications in schedule B were relatively low (Table 5). We hypothesize that the administration of only two cycles of bevacizumab, and the resulting longer interval between its last administration and surgery, may have helped to reduce the occurrence of surgical complications. However, compared to the $2 \%$ rate of re-operation reported in larger phase III trial in patients treated with preoperative fluoropyrimidine alone during RT [30], the $9 \%$ rate observed with the sequential schedule is higher. Nevertheless, this rate is similar to that reported with other intensified treatment approaches, including our previous experience without bevacizumab [3, 31]. Notably when an intensified approach was used in combination with bevacizumab as preoperative treatment, an even higher re-operation rate was reported [19].

Our study has some potential limitations that deserve special consideration. Its major weakness is that it was a single center, non-randomized phase-2 trial, with a relatively small sample size. Furthermore, evidence is emerging that a margin of $\leq 1 \mathrm{~mm}$ from the MRF by MRI may be adequate 
Table 5: Postoperative Complications and late toxicities

\begin{tabular}{|c|c|c|}
\hline & Schedule A $(n=16)$ & Schedule B $(n=46)$ \\
\hline Patients with at least one complication, $n(\%)$ & $8(53 \%)$ & $13(28 \%)$ \\
\hline Anastomotic fistula & 3 & 3 \\
\hline Rectovaginal fistula & 1 & - \\
\hline Pelvic infection & 2 & 5 \\
\hline Anastomotic leak & 1 & 2 \\
\hline Intestinal ischemia & 1 & - \\
\hline Wound healing complication & - & 1 \\
\hline Urinary retention & - & 3 \\
\hline Rectal bleeding & - & 1 \\
\hline Stoma complication & - & 1 \\
\hline Anastomotic stenosis & - & 2 \\
\hline Patients with at least one late toxicity, $n(\%)$ & $6(40 \%)$ & $19(41 \%)$ \\
\hline \multicolumn{3}{|l|}{ Sexual dysfunction } \\
\hline Erectile dysfunction & 2 & 4 \\
\hline Retrograde ejaculation & - & 1 \\
\hline Dyspareunia & 1 & 1 \\
\hline Anorectal dysfunction & & - \\
\hline Fecal and gas incontinence & 2 & 7 \\
\hline Higher stool frequency & 2 & 5 \\
\hline Constipation & - & 1 \\
\hline Urinary dysfunction & & 1 \\
\hline Neurogenic bladder & - & 1 \\
\hline
\end{tabular}

to identify patients at risk of CRM involvement [32], as opposed to the $5 \mathrm{~mm}$ threshold previously accepted [33]. A recent multicenter study showed that a cut-off of $2 \mathrm{~mm}$ from the MRF may help select patients in whom an intensive preoperative treatment is needed [34]. In our study, the tumor was located within $2 \mathrm{~mm}$ of MRF in $83 \%$ of patients and most patients had additional high-risk factors. Moreover, 93\% of patients showed clinical lymph node involvement and $15 \%$ had metastatic disease. Therefore, it seems unlikely that our results were influenced by favorable patient selection.

In conclusion, taking into account the few doses of bevacizumab associated with preoperative CRT, its scheduling seems to be crucial to potentiate the combination. We may hypothesize that, in this setting, bevacizumab might improve the delivery of cytotoxic drugs and oxygen to cancer cells through a reduction of the interstitial fluid pressure ("vessel normalization effect"), that has been proven to occur few days after a single drug administration [5], rather than through the reduction of vessel density ("tumor-starving effect").
If so, the sequential administration of bevacizumab and CRT, as opposed to concurrent, exploits this synergism at best. Of course, further studies are needed to validate this approach and better understand its underlying molecular mechanisms. Therefore, we are currently conducting a phase-3 randomized study comparing the two bevacizumab schedules in combination with FOLFOX/ OXXEL regimens in metastatic colorectal cancer patients (OBELICS study, NCT01718873).

\section{MATERIALS AND METHODS}

The BRANCH (Bevacizumab, RAdiotherapy aNd CHemotherapy) trial was an open label, nonrandomized, single center, phase-2 clinical study (Eudract number: 2008-003989-26; Clinicaltrials.gov number: NCT01481545), approved by the local ethical committee and conducted in accordance to the Declaration of Helsinki. Signed written informed consent was obtained from each patient before accrual. 
Table 6: Main published phase II studies using bevacizumab in combination with preoperative radiochemotherapy

\begin{tabular}{|c|c|c|c|c|c|c|c|}
\hline Author & Reference & Treatment schedule & $\begin{array}{l}\text { Eligible } \\
\text { patients }\end{array}$ & $\begin{array}{c}\text { Main } \\
\text { Toxicity } \\
\text { G3/G4 (\%) }\end{array}$ & $\begin{array}{l}\text { Postoperative } \\
\text { complications* } \\
(\%)\end{array}$ & $\begin{array}{l}\text { Complete } \\
\text { tumor } \\
\text { regression** } \\
(\%)\end{array}$ & Survival \\
\hline $\begin{array}{l}\text { Willett } \\
\text { et al. }\end{array}$ & {$[14,15]$} & $\begin{array}{l}\text { RT } 50.4 \text { Gy; BEV } \\
\text { days }-14,1,15,29 \\
5 \mathrm{FU} 225 \mathrm{mg} / \mathrm{m}^{2} / \mathrm{d} \text { days } \\
1-38\end{array}$ & $\begin{array}{c}\mathrm{T} 3-\mathrm{T} 4 \\
(n=32)\end{array}$ & Diarrhea 22 & $\begin{array}{c}\text { Minor } 28 \\
\text { Major } 6\end{array}$ & $5 / 32(16)$ & $\begin{array}{c}\text { 5-years } \\
\text { DFS } 77 \% \\
5 \text {-years } \\
\text { OS } 100 \%\end{array}$ \\
\hline $\begin{array}{l}\text { Crane } \\
\text { et al. }\end{array}$ & [16] & $\begin{array}{l}\text { RT } 50.4 \text { Gy; BEV days } 1 \text {, } \\
15,29 ; \\
\text { Cap } 900 \mathrm{mg} / \mathrm{m}^{2} \text { b.i.d. days } \\
1-38\end{array}$ & $\begin{array}{c}\mathrm{T} 3-\mathrm{T} 4 \\
\text { and/or } \mathrm{N}+ \\
(n=25)\end{array}$ & 0 & $\begin{array}{l}\text { Minor } 20 \\
\text { Major } 12\end{array}$ & $8 / 25(32)$ & $\begin{array}{c}\text { 2-years } \\
\text { DFS 69\% } \\
\text { 2-years } \\
\text { OS } 95 \%\end{array}$ \\
\hline $\begin{array}{l}\text { Noguè } \\
\text { et al. }\end{array}$ & [17] & $\begin{array}{l}\text { Induction: BEV+XELOX } \\
\times 4 ; \\
\text { RT } 50.4 \mathrm{~Gy} \text {; BEV days } 1 \text {, } \\
15,29 ; \\
\text { Cap } 825 \mathrm{mg} / \mathrm{m}^{2} \text { b.i.d. days } \\
1-38\end{array}$ & \begin{tabular}{|c} 
MRI- \\
defined \\
high-risk \\
T3-T4 \\
and/or N+ \\
$(n=47)$
\end{tabular} & $\begin{array}{c}\text { Diarrhea 11 } \\
\text { Neutropenia } \\
6\end{array}$ & $\begin{array}{l}\text { Minor } 34 \\
\text { Major } 24\end{array}$ & $16 / 47(34)$ & NS \\
\hline $\begin{array}{l}\text { Velenik } \\
\text { et al. }\end{array}$ & [18] & $\begin{array}{l}\text { RT } 50.4 \text { Gy; BEV } \\
\text { days }-14,1,15,29 ; \\
\text { Cap } 825 \mathrm{mg} / \mathrm{m}^{2} \text { b.i.d. days } \\
1-38\end{array}$ & $\begin{array}{c}\mathrm{T} 3-\mathrm{T} 4 \\
\text { and/or } \mathrm{N}+ \\
(n=61)\end{array}$ & $\begin{array}{c}\text { Dermatitis } \\
10\end{array}$ & $\begin{array}{l}\text { Minor } 52 \\
\text { Major } 10\end{array}$ & 8/61 (13) & NS \\
\hline $\begin{array}{l}\text { Dipetrillo } \\
\text { et al. }\end{array}$ & [19] & $\begin{array}{l}\text { Induction: } \mathrm{BEV}+\mathrm{FOLFOX} \\
\times 2 ; \text { RT } 50.4 \mathrm{~Gy} ; \\
\text { BEV days } 1,15,29 ; \\
5 \mathrm{FU} 200 \mathrm{mg} / \mathrm{m}^{2} / \mathrm{d} \text { days } \\
1-38 ; \\
\text { OX } 40 \mathrm{mg} / \mathrm{m}^{2} \text { weekly } \times 6 \\
\text { weeks }\end{array}$ & $\begin{array}{c}\mathrm{T} 3-\mathrm{T} 4 \\
\text { and/or } \mathrm{N}+ \\
(n=26)\end{array}$ & $\begin{array}{c}\text { Diarrhea } 44 \\
\text { Neutropenia } \\
20\end{array}$ & Minor 36 & $5 / 26(19)$ & $\begin{array}{c}\text { 3-years } \\
\text { DFS 65\% } \\
\text { 3-years } \\
\text { OS } 95 \%\end{array}$ \\
\hline $\begin{array}{l}\text { Gasparini } \\
\text { et al. }\end{array}$ & [20] & $\begin{array}{l}\text { RT } 50.4 \text { Gy; BEV } \\
\text { days }-14,1,15,29 ; \\
\text { Cap } 825 \mathrm{mg} / \mathrm{m}^{2} \text { b.i.d. days } \\
1-38\end{array}$ & $\begin{array}{c}\mathrm{T} 3-\mathrm{T} 4 \\
\text { and/or } \mathrm{N}+ \\
(n=43)\end{array}$ & Diarrhea 7 & $\begin{array}{c}\text { Minor } 7 \\
\text { Major }^{\circ}\end{array}$ & $6 / 43(14)$ & $\begin{array}{c}\text { 3-years } \\
\text { DFS } 75 \%\end{array}$ \\
\hline $\begin{array}{l}\text { Kennecke } \\
\text { et al. }\end{array}$ & [21] & $\begin{array}{l}\text { RT } 50.4 \mathrm{~Gy} ; \text { BEV } \\
\text { days }-14,1,15,29 \text {; } \\
\text { Cap } 825 \mathrm{mg} / \mathrm{m}^{2} \text { b.i.d. days } \\
1-14 \text { and } 22-35 \text {; } \\
\text { OX } 50 \mathrm{mg} / \mathrm{m}^{2} \text { days } 1,8 \text {, } \\
\text { 22, and } 29\end{array}$ & \begin{tabular}{|l} 
High-risk \\
T3-T4 \\
and/or N+ \\
or \\
anyTNM1 \\
$(n=42)$
\end{tabular} & $\begin{array}{c}\text { Diarrhea } 24 \\
\text { Rectal pain } \\
10\end{array}$ & $\begin{array}{l}\text { Minor } 53 \\
\text { Major } 10\end{array}$ & $9 / 42(21)$ & NS \\
\hline $\begin{array}{l}\text { Spigel } \\
\text { et al. }\end{array}$ & [22] & $\begin{array}{l}\text { RT } 50.4 \text { Gy; BEV days } 1 \text {, } \\
15 ; \\
5 \mathrm{FU} 225 \mathrm{mg} / \mathrm{m}^{2} / \mathrm{d} \text { days } \\
1-42\end{array}$ & $\begin{array}{c}\mathrm{T} 3-\mathrm{T} 4 \\
\text { and/or } \mathrm{N}+ \\
(n=35)\end{array}$ & \begin{tabular}{|c|} 
Thrombo- \\
cytopenia 9 \\
Diarrhea 6
\end{tabular} & $\begin{array}{l}\text { Minor } 3 \\
\text { Major } 3\end{array}$ & $10 / 35(29)$ & $\begin{array}{c}1 \text {-years } \\
\text { DFS } 85 \%\end{array}$ \\
\hline $\begin{array}{l}\text { Landry } \\
\text { et al. }\end{array}$ & [23] & $\begin{array}{l}\text { RT } 50.4 \mathrm{~Gy} \text {; BEV days } 1 \text {, } \\
15,29 ; \\
\text { Cap } 825 \mathrm{mg} / \mathrm{m}^{2} \text { b.i.d. days } \\
1-38 ; \\
\text { OX } 50 \mathrm{mg} / \mathrm{m}^{2} \text { weekly } \times 5 \\
\text { weeks }\end{array}$ & $\begin{array}{c}\mathrm{T} 3-\mathrm{T} 4 \\
(n=54)\end{array}$ & \begin{tabular}{|c|} 
Rectal pain \\
17 \\
Diarrhea \\
$13^{\S \S}$
\end{tabular} & $\begin{array}{c}\text { Minor } 49 \\
\text { Major } 6\end{array}$ & $9 / 54(17)$ & NS \\
\hline
\end{tabular}

(Continued) 


\begin{tabular}{|c|c|c|c|c|c|c|c|}
\hline Author & Reference & Treatment schedule & $\begin{array}{l}\text { Eligible } \\
\text { patients }\end{array}$ & $\begin{array}{c}\text { Main } \\
\text { Toxicity } \\
\text { G3/G4 (\%) }\end{array}$ & $\begin{array}{l}\text { Postoperative } \\
\text { complications* } \\
\text { (\%) }\end{array}$ & $\begin{array}{l}\text { Complete } \\
\text { tumor } \\
\text { regression** } \\
(\%)\end{array}$ & Survival \\
\hline $\begin{array}{l}\text { Dellas } \\
\text { et al. }\end{array}$ & [24] & $\begin{array}{l}\text { RT } 50.4 \mathrm{~Gy} \text {; BEV days } 1 \text {, } \\
15,29 ; \\
\text { Cap } 825 \mathrm{mg} / \mathrm{m}^{2} \text { b.i.d. days } \\
1-14 \text { and } 22-35 ; \\
\text { OX } 50 \mathrm{mg} / \mathrm{m}^{2} \text { days } 1,8 \text {, } \\
22 \text {, and } 29\end{array}$ & $\begin{array}{c}\mathrm{T} 3-\mathrm{T} 4 \\
\text { and/or } \\
\mathrm{N}+\text { or } \\
\text { any TNM } \\
\text { 1livrs } \\
(n=69)\end{array}$ & Diarrhea 4 & Minor 55 & $12 / 69(17)$ & NS \\
\hline $\begin{array}{l}\text { Blasz- } \\
\text { kowsky } \\
\text { et al. }\end{array}$ & [25] & $\begin{array}{l}\text { RT } 50.4 \text { Gy; BEV days } \\
-14,1,15,29 ; \\
5 F U ~ 225 \mathrm{mg} / \mathrm{m}^{2} / \mathrm{d} \text { days } \\
1-38 ; \\
\text { erlo } 100 \mathrm{mg} / \mathrm{m}^{2} / \mathrm{d} \text { days } \\
1-38\end{array}$ & $\begin{array}{c}\mathrm{T} 3-\mathrm{T} 4 \\
(n=26)\end{array}$ & \begin{tabular}{|c} 
Lympho- \\
penia 46 \\
Diarrhea 19
\end{tabular} & Minor 65 & $7 / 26(27)$ & $\begin{array}{c}3 \text {-years } \\
\text { DFS } 75 \%\end{array}$ \\
\hline $\begin{array}{l}\text { Borg } \\
\text { et al. }\end{array}$ & [26] & $\begin{array}{l}\text { Induction: BEV+FOLFOX } \\
\times 6 \text {; } \\
\text { RT } 45 \mathrm{~Gy} ; \mathrm{BEV} \text { days-14, } \\
1,15,29 ; \\
5 \mathrm{FU} 225 \mathrm{mg} / \mathrm{m}^{2} / \mathrm{d} \times 5 \\
\text { days/week }\end{array}$ & $\begin{array}{c}\text { MRI- } \\
\text { defined } \\
\text { locally } \\
\text { advanced } \\
\text { T3 } \\
(n=46)\end{array}$ & $\begin{array}{c}\text { Neutropenia } \\
20 \\
\text { Diarrhea } 6 \\
\text { Gastroin- } \\
\text { testinal } \\
\text { perforation } \\
4\end{array}$ & Minor 22 & $10 / 46(22)$ & NS \\
\hline $\begin{array}{l}\text { Borg } \\
\text { et al. }\end{array}$ & [26] & $\begin{array}{l}\text { RT } 45 \text { Gy; BEV days }-14 \text {, } \\
1,15,29 ; \\
5 \mathrm{FU} 225 \mathrm{mg} / \mathrm{m}^{2} / \mathrm{d} \times 5 \\
\text { days/week }\end{array}$ & $\begin{array}{c}\text { MRI- } \\
\text { defined } \\
\text { locally } \\
\text { advanced } \\
\text { T3 } \\
(n=45)\end{array}$ & $\begin{array}{l}\text { Diarrhea } 6 \\
\text { Proctitis } 4\end{array}$ & Minor 22 & $5 / 45(11)$ & NS \\
\hline $\begin{array}{l}\text { Present } \\
\text { study } \\
\text { Schedule } \\
\text { B }\end{array}$ & & $\begin{array}{l}\text { RT } 45 \text { Gy; BEV days }-4, \\
11 ; \\
\text { OX } 100 \mathrm{mg} / \mathrm{m}^{2}+\text { Tom } 2.5 \\
\mathrm{mg} / \mathrm{m}^{2} \text { days } 1,15 \text { and } 29 ; \\
5 \mathrm{FU} 800 \mathrm{mg} / \mathrm{m}^{2}+\text { LFA } 250 \\
\mathrm{mg} / \mathrm{m}^{2} \text { days } 2,16 \text { and } 30\end{array}$ & $\begin{array}{c}\text { MRI- } \\
\text { defined } \\
\text { high-risk } \\
\text { T3-T4 } \\
\text { and/or } \\
\text { N+ or any } \\
\text { TNM1rs } \\
(n=46)\end{array}$ & $\begin{array}{c}\text { Neutropenia } \\
30 \\
\text { Diarrea } 6\end{array}$ & $\begin{array}{c}\text { Minor } 19 \\
\text { Major } 9\end{array}$ & $23 / 46(50)$ & $\begin{array}{c}\text { 5-years } \\
\text { PFS } 80 \% \\
\text { 5-years } \\
\text { OS } 85 \%\end{array}$ \\
\hline
\end{tabular}

$\mathrm{RT}=$ radiotherapy; $\mathrm{BEV}=$ bevacizumab; 5-FU = 5-fluorouracil; Cap = capecitabine; $\mathrm{OX}=$ oxaliplatin; LFA = folinic acid; erlo = erlotinib; $d$ = day; .livrs = single resectable liver metastasis; $r s=$ resectable; $\mathrm{MRI}$ = magnetic resonance imaging; NS $=$ not specified. $\mathrm{DFS}=$ disease free survival; $\mathrm{PFS}=$ progression free survival; OS = overall survival

*Postoperative surgery-related complications

Major/minor requiring/not requiring surgical reintervention or drainage

**Various tumor regression grading systems used

One postoperative death

${ }^{\S}$ Two (4\%) toxicity-related deaths (one sudden death and one ketoacidosis)

${ }^{\S}$ One toxicity-related death (aspiration)

\section{Patient selection}

The study enrolled patients with pathologically confirmed untreated high-risk rectal adenocarcinoma within 15 $\mathrm{cm}$ from the anal margin. High-risk was defined a tumor with concomitant resectable metastases and/or any of the following MRI features: T4; anyTN1-2; T3N0 tumors located in the lower third of the rectum and/or whose radial margin was $\leq 5 \mathrm{~mm}$ from MRF. Tumors with radial margin $\leq 5 \mathrm{~mm}$ from MRF, defined by MRI, were considered to have potentially positive CRM. Other main eligibility criteria were: age $\geq 18$ years; ECOG performance status $\leq 2$; adequate bone marrow, renal, and liver function; absence of concurrent uncontrolled medical condition; no previous malignant disease. 


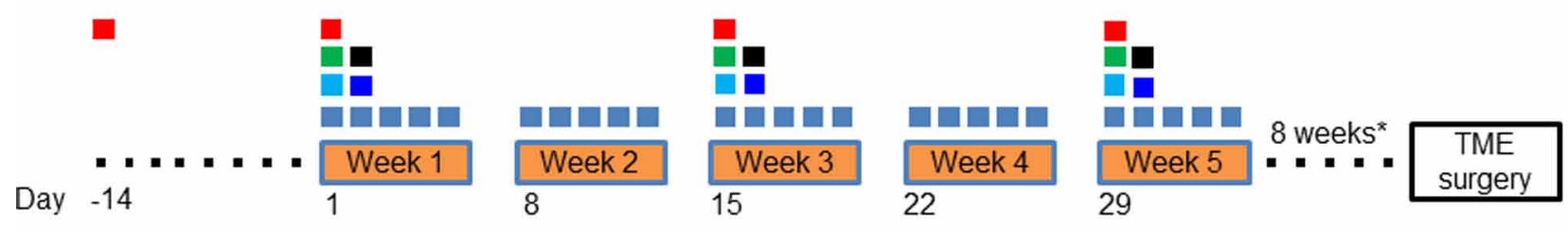

Sequential Bevacizumab Schedule (B)

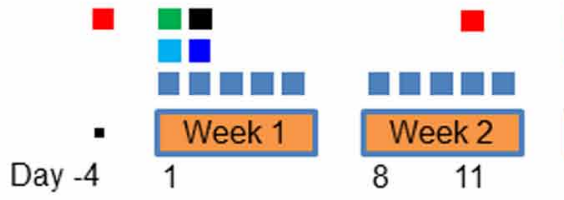

*Two additional cycles of chemotherapy with one administration of bevacizumab according to the schedule after the end of RT were permitted in the patients with metastatic disease

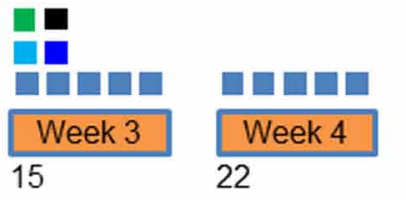

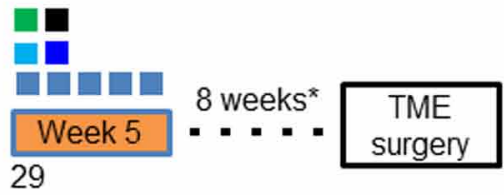

Oxaliplatin $100 \mathrm{mg} / \mathrm{m}^{2}$ Raltitrexed $2.5 \mathrm{mg} / \mathrm{m}^{2}$

Levofolinic acid $250 \mathrm{mg} / \mathrm{m}^{2}$ 5-FU $800 \mathrm{mg} / \mathrm{m}^{2}$

Radiotherapy $1.8 \mathrm{~Gy} /$ day $x 25$ fraction $=45$ Gy

Bevacizumab $5 \mathrm{mg} / \mathrm{kg}$

Figure 2: Treatment schedules.

Baseline work-up was completed within 6 weeks before the registration and included: clinical examination, laboratory tests, recto-colonoscopy and endorectal ultrasound; carcinoembryonic antigen (CEA) serum level; whole body contrast enhanced computed tomography (CT); MRI of the pelvis. Imaging studies were blindly reviewed by two radiologists (AP and VG) and in case of discrepancy the worse TNM was assigned.

Biomarker studies on tumor and blood samples and $\left[{ }^{18} \mathrm{~F}\right]$-2-fluoro-2-deoxy-D-glucose positron emission tomography $\left({ }^{18} \mathrm{FDG}-\mathrm{PET}\right)$ evaluation were also performed at baseline, during treatment and before surgery. Results of these studies will be described in separate reports.

\section{Study Procedures}

\section{Treatment plan}

The total dose of RT was 45 Gy delivered in 25 fractions of $1.8 \mathrm{~Gy}, 5$ days/week. The clinical target volume (CTV) included the tumor, with margins of $2-3 \mathrm{~cm}$ depending on tumor direction, mesorectum and regional lymph nodes. The planning target volume was defined as CTV $+1 \mathrm{~cm}$ margin.

Chemotherapy given during RT consisted of three biweekly cycles of infusional oxaliplatin, 100 $\mathrm{mg} / \mathrm{m}^{2}$ followed by raltitrexed, $2.5 \mathrm{mg} / \mathrm{m}^{2}$ on day 1 , and levo-folinic acid, $250 \mathrm{mg} / \mathrm{m}^{2}$ followed by bolus of 5-fluorouracil, $800 \mathrm{mg} / \mathrm{m}^{2}$ on day 2 .

Bevacizumab $5 \mathrm{mg} / \mathrm{kg}$ was administered 2 weeks before the start of CRT, and on the same day of oxaliplatin and raltitrexed for 3 cycles (treatment days: $-14,1,15$ and 29; concomitant schedule A) or 4 days prior to the first and second cycle of chemotherapy (treatment days: -4 , and 11; sequential schedule B) (Figure 2). Two additional cycles of chemotherapy with one bevacizumab infusion, using the previously employed timing schedule, were allowed after the end of CRT in patients with metastatic disease.

CRT had to be temporarily stopped in case of grade $\geq 3$ toxicity. Dose adjustments for adverse events were reported previously [35]. Total mesorectal excision (TME) was planned 8 weeks $( \pm 1)$ after the last day of RT. The choice of surgical procedure for primary tumor, anterior or abdominal-peritoneal resection, and metastases was based on restaging. Fecal diversion to protect the anastomosis was performed by means of a loop ileostomy, which was later reversed after endoscopic assessment of anastomotic integrity. All patients underwent clinical tumor response assessment before surgery with the same imaging modalities that were used for the inclusion into the study. 


\section{Pathology}

Tumor regression grade (TRG) was blindly measured according to the Mandard scale [36] by two pathologists (GB and FT). In case of discrepancy between the two the worse TRG score was assigned.

A complete pathologic response (ypCR,) was defined as the absence of viable tumor cells in the primary tumor and lymph nodes (ypT0N0). Radical resection (R0) was defined as macroscopic and microscopic tumor-free resection for both primary tumor $(\mathrm{CRM}>1 \mathrm{~mm})$ and metastatic disease (margins $>1 \mathrm{~mm}$ from tumor).

\section{Adjuvant treatment and follow up}

Four months of post-operative FOLFOX4 regimen, no earlier than 4 weeks after surgery, was planned only in patients with $\mathrm{ypN}+$ or $\mathrm{CRM} \leq 1 \mathrm{~mm}$ at pathology examination, or for those with baseline metastatic disease eventually resected with an R0/R1 status.

Clinical examination, CEA serum level, whole body CT and pelvic MRI, were performed every 4 months for the first 2 years of follow up, every 6 months for the next 3 years, and annually thereafter.

\section{Statistical design and analysis}

The primary end point of this study was the rate of TRG1. To establish the sample size, the Simon's two-stage design was applied [37]. Setting $\alpha$ and $\beta$ errors at 0.05 and 0.20 , respectively, and defining as the minimum activity of interest (p0) a TRG1 rate of $30 \%$, in order to accept the alternative hypothesis ( $\mathrm{p} 1$ ) of a TRG1 rate $\geq 50 \%$, at least 6 TRG1 in the first 15 patients and at least 19 TRG1 among a total of 46 patients would need to be reported in the first and second stage, respectively.

The study protocol provided that the sequential schedule of bevacizumab would be evaluated only if the required number of TRG1 was not reached with the concomitant schedule. Other endpoints included toxicity, surgical morbidity, and long-term outcome.

Toxicities, were graded according to the National Cancer Institute common toxicity criteria (NCI CTCVersion 3). Postoperative complications were included in this report when occurring within 90 days from surgery. Late toxicity was assessed using the SOMA-LENT scale [38]. Proportions were calculated with their exact $95 \%$ confidence interval (CI).

PFS was calculated from the date of initial treatment until tumor progression or relapse, death for any cause or last follow-up. OS was calculated from the date of initial treatment to the date of death for any cause or last followup. PFS and OS rates were estimated with their 95\% CI using the Kaplan-Meier method. Analysis was based on the intention-to-treat, and was performed using SPSS statistical analysis software (version 12.0; SPSS Inc.). No comparison between the two cohorts of patients was planned. The end point database was updated in December 2014.

\section{ACKNOWLEDGMENTS}

We are grateful to Dr. Valeria Vicario and Dr. Alessandra Trocino from the National Cancer Institute of Naples for providing excellent bibliographic service and assistance.

\section{FUNDING}

The study was a no-profit trial partially supported by research grants from the Italian Ministry of Health to A. Avallone (RF-2009-1539464) and to A. Budillon (RF2011-02346914). Bevacizumab was kindly provided by Hoffmann-La Roche, Italy.

\section{CONFLICTS OF INTEREST}

Antonio Avallone: honoraria from Roche for participation in conferences as speaker and in advisory board meetings. All other authors have declared no conflict interest.

\section{REFERENCES}

1. Sauer R, Becker H, Hohenberger W, Rodel C, Wittekind C, Fietkau R, Martus P, Tschmelitsch J, Hager E, Hess CF, Karstens JH, Liersch T, Schmidberger H, Raab R. Preoperative versus postoperative chemoradiotherapy for rectal cancer. N Engl J Med. 2004; 351:1731-1740.

2. Dewdney A, Cunningham D, Chau I. Selecting patients with locally advanced rectal cancer for neoadjuvant treatment strategies. Oncologist. 2013; 18:833-842.

3. Avallone A, Delrio P, Pecori B, Tatangelo F, Petrillo A, Scott N, Marone P, Aloi L, Sandomenico C, Lastoria S, Iaffaioli VR, Scala D, Iodice G, Budillon A, Comella P. Oxaliplatin plus dual inhibition of thymidilate synthase during preoperative pelvic radiotherapy for locally advanced rectal carcinoma: long-term outcome. Int J Radiat Oncol Biol Phys. 2011; 79:670-676.

4. Kozin SV, Boucher Y, Hicklin DJ, Bohlen P, Jain RK, Suit HD. Vascular endothelial growth factor receptor2-blocking antibody potentiates radiation-induced longterm control of human tumor xenografts. Cancer Res. $2001 ; 61: 39-44$.

5. Willett CG, Boucher Y, di Tomaso E, Duda DG, Munn LL, Tong RT, Chung DC, Sahani DV, Kalva SP, Kozin SV, Mino M, Cohen KS, Scadden DT, Hartford AC, Fischman AJ, Clark JW, et al. Direct evidence that the VEGF-specific antibody bevacizumab has antivascular effects in human rectal cancer. Nat Med. 2004; 10:145-147.

6. Glynne-Jones R, Hadaki M, Harrison M. The status of targeted agents in the setting of neoadjuvant radiation therapy in locally advanced rectal cancers. J Gastrointest Oncol. 2013; 4:264-284. 
7. Carmeliet P, Jain RK. Principles and mechanisms of vessel normalization for cancer and other angiogenic diseases. Nature Reviews Drug Discovery. 2011; 10:417-427.

8. Mazzone M, Dettori D, Leite de Oliveira R, Loges S, Schmidt T, Jonckx B, Tian YM, Lanahan AA, Pollard P, Ruiz de Almodovar C, De Smet F, Vinckier S, Aragones J, Debackere K, Luttun A, Wyns S, et al. Heterozygous deficiency of PHD2 restores tumor oxygenation and inhibits metastasis via endothelial normalization. Cell. 2009; 136:839-851.

9. Tong RT, Boucher Y, Kozin SV, Winkler F, Hicklin DJ, Jain RK. Vascular normalization by vascular endothelial growth factor receptor 2 blockade induces a pressure gradient across the vasculature and improves drug penetration in tumors. Cancer Res. 2004; 64:3731-3736.

10. Winkler F, Kozin SV, Tong RT, Chae SS, Booth MF, Garkavtsev I, Xu L, Hicklin DJ, Fukumura D, di Tomaso E, Munn LL, Jain RK. Kinetics of vascular normalization by VEGFR2 blockade governs brain tumor response to radiation: role of oxygenation, angiopoietin-1, and matrix metalloproteinases. Cancer Cell. 2004; 6:553-563.

11. Cervantes A, Glynne-Jones R. Adjuvant chemotherapy for rectal cancer after preoperative radiation or chemoradiation: One size does not fit all. Ann Oncol. 2015; 26:617-619.

12. Fokas E, Liersch T, Fietkau R, Hohenberger W, Beissbarth T, Hess C, Becker H, Ghadimi M, Mrak K, Merkel S, Raab HR, Sauer R, Wittekind C, Rodel C. Tumor regression grading after preoperative chemoradiotherapy for locally advanced rectal carcinoma revisited: updated results of the CAO/ARO/AIO-94 trial. J Clin Oncol. 2014; 32:1554-1562.

13. Maas M, Nelemans PJ, Valentini V, Das P, Rodel C, Kuo LJ, Calvo FA, Garcia-Aguilar J, Glynne-Jones R, Haustermans K, Mohiuddin M, Pucciarelli S, Small W Jr, Suarez J, Theodoropoulos G, Biondo S, et al. Long-term outcome in patients with a pathological complete response after chemoradiation for rectal cancer: a pooled analysis of individual patient data. Lancet Oncol. 2010; 11:835-844.

14. Hong YS, Nam BH, Kim KP, Kim JE, Park SJ, Park YS, Park JO, Kim SY, Kim TY, Kim JH, Ahn JB, Lim SB, Yu CS, Kim JC, Yun SH, Park JH, et al. Oxaliplatin, fluorouracil, and leucovorin versus fluorouracil and leucovorin as adjuvant chemotherapy for locally advanced rectal cancer after preoperative chemoradiotherapy (ADORE): an openlabel, multicentre, phase 2, randomised controlled trial. Lancet Oncol. 2014; 15:1245-1253.

15. Glynne-Jones R, Anyamene N, Moran B, Harrison M. Neoadjuvant chemotherapy in MRI-staged high-risk rectal cancer in addition to or as an alternative to preoperative chemoradiation?. Ann Oncol. 2012; 23:2517-2526.

16. Willett CG, Duda DG, di Tomaso E, Boucher Y, Ancukiewicz M, Sahani DV, Lahdenranta J, Chung DC, Fischman AJ, Lauwers GY, Shellito P, Czito BG, Wong TZ, Paulson E, Poleski M, Vujaskovic Z, et al. Efficacy, safety, and biomarkers of neoadjuvant bevacizumab, radiation therapy, and fluorouracil in rectal cancer: a multidisciplinary phase II study. Journal of clinical oncology: official journal of the American Society of Clinical Oncology. 2009; 27:3020-3026.

17. Willett CG, Duda DG, Ancukiewicz M, Shah M, Czito BG, Bentley R, Poleski M, Fujita H, Lauwers GY, Carroll M, Tyler D, Mantyh C, Shellito P, Chung DC, Clark JW, Jain RK. A safety and survival analysis of neoadjuvant bevacizumab with standard chemoradiation in a phase I/ II study compared with standard chemoradiation in locally advanced rectal cancer. The oncologist. 2010; 15:845-851.

18. Crane CH, Eng C, Feig BW, Das P, Skibber JM, Chang GJ, Wolff RA, Krishnan S, Hamilton S, Janjan NA, Maru DM, Ellis LM, Rodriguez-Bigas MA. Phase II trial of neoadjuvant bevacizumab, capecitabine, and radiotherapy for locally advanced rectal cancer. Int J Radiat Oncol Biol Phys. 2010; 76:824-830.

19. Nogue M, Salud A, Vicente P, Arrivi A, Roca JM, Losa F, Ponce J, Safont MJ, Guasch I, Moreno I, Ruiz A, Pericay C. Addition of bevacizumab to XELOX induction therapy plus concomitant capecitabine-based chemoradiotherapy in magnetic resonance imaging-defined poor-prognosis locally advanced rectal cancer: the AVACROSS study. The oncologist. 2011; 16:614-620.

20. Velenik V, Ocvirk J, Music M, Bracko M, Anderluh F, Oblak I, Edhemovic I, Brecelj E, Kropivnik M, Omejc M. Neoadjuvant capecitabine, radiotherapy, and bevacizumab (CRAB) in locally advanced rectal cancer: results of an open-label phase II study. Radiation Oncology. 2011; 6:105.

21. Dipetrillo T, Pricolo V, Lagares-Garcia J, Vrees M, Klipfel A, Cataldo T, Sikov W, McNulty B, Shipley J, Anderson E, Khurshid H, Oconnor B, Oldenburg NB, Radie-Keane K, Husain S, Safran H. Neoadjuvant bevacizumab, oxaliplatin, 5-fluorouracil, and radiation for rectal cancer. Int J Radiat Oncol Biol Phys. 2012; 82:124-129.

22. Gasparini G, Torino F, Ueno T, Cascinu S, Troiani T, Ballestrero A, Berardi R, Shishido J, Yoshizawa A, Mori Y, Nagayama S, Morosini P, Toi M. A phase II study of neoadjuvant bevacizumab plus capecitabine and concomitant radiotherapy in patients with locally advanced rectal cancer. Angiogenesis. 2012; 15:141-150.

23. Kennecke H, Berry S, Wong R, Zhou C, Tankel K, Easaw J, Rao S, Post J, Hay J. Pre-operative bevacizumab, capecitabine, oxaliplatin and radiation among patients with locally advanced or low rectal cancer: a phase II trial. European Journal of Cancer. 2012; 48:37-45.

24. Spigel DR, Bendell JC, McCleod M, Shipley DL, Arrowsmith E, Barnes EK, Infante JR, Burris HA 3rd, Greco FA, Hainsworth JD. Phase II study of bevacizumab and chemoradiation in the preoperative or adjuvant treatment of patients with stage II/III rectal cancer. Clinical Colorectal Cancer. 2012; 11:45-52.

25. Landry JC, Feng Y, Cohen SJ, Staley CA 3rd, Whittington R, Sigurdson ER, Nimeiri H, Verma U, Prabhu RS, Benson 
AB. Phase 2 study of preoperative radiation with concurrent capecitabine, oxaliplatin, and bevacizumab followed by surgery and postoperative 5-fluorouracil, leucovorin, oxaliplatin (FOLFOX), and bevacizumab in patients with locally advanced rectal cancer: ECOG 3204. Cancer. 2013; 119:1521-1527.

26. Dellas K, Hohler T, Reese T, Wurschmidt F, Engel E, Rodel C, Wagner W, Richter M, Arnold D, Dunst J. Phase II trial of preoperative radiochemotherapy with concurrent bevacizumab, capecitabine and oxaliplatin in patients with locally advanced rectal cancer. Radiation Oncology. 2013; 8:90.

27. Blaszkowsky LS, Ryan DP, Szymonifka J, Borger DR, Zhu AX, Clark JW, Kwak EL, Mamon HJ, Allen JN, Vasudev E, Shellito PC, Cusack JC, Berger DL, Hong TS. Phase I/ II study of neoadjuvant bevacizumab, erlotinib and 5-fluorouracil with concurrent external beam radiation therapy in locally advanced rectal cancer. Annals of oncology: official journal of the European Society for Medical Oncology / ESMO. 2014; 25:121-126.

28. Borg C, Andre T, Mantion G, Boudghene F, Mornex F, Maingon P, Adenis A, Azria D, Piutti M, Morsli O, Bosset JF. Pathological response and safety of two neoadjuvant strategies with bevacizumab in MRI-defined locally advanced $\mathrm{T} 3$ resectable rectal cancer: a randomized, noncomparative phase II study. Annals of oncology: official journal of the European Society for Medical Oncology / ESMO. 2014; 25:2205-2210.

29. Zhang D, Hedlund EM, Lim S, Chen F, Zhang Y, Sun B, Cao Y. Antiangiogenic agents significantly improve survival in tumor-bearing mice by increasing tolerance to chemotherapy-induced toxicity. Proc Natl Acad Sci U S A. 2011; 108:4117-4122.

30. Rodel C, Liersch T, Becker H, Fietkau R, Hohenberger W, Hothorn T, Graeven U, Arnold D, Lang-Welzenbach M, Raab HR, Sulberg H, Wittekind C, Potapov S, Staib L, Hess C, Weigang-Kohler K, et al. Preoperative chemoradiotherapy and postoperative chemotherapy with fluorouracil and oxaliplatin versus fluorouracil alone in locally advanced rectal cancer: initial results of the German CAO/ARO/AIO04 randomised phase 3 trial. The Lancet Oncology. 2012; 13:679-687.

31. Fernandez-Martos C, Pericay C, Aparicio J, Salud A, Safont M, Massuti B, Vera R, Escudero P, Maurel J, Marcuello E, Mengual JL, Saigi E, Estevan R, Mira M,
Polo S, Hernandez A, et al. Phase II, randomized study of concomitant chemoradiotherapy followed by surgery and adjuvant capecitabine plus oxaliplatin (CAPOX) compared with induction CAPOX followed by concomitant chemoradiotherapy and surgery in magnetic resonance imagingdefined, locally advanced rectal cancer: Grupo cancer de recto 3 study. Journal of clinical oncology: official journal of the American Society of Clinical Oncology. 2010; 28:859-865.

32. Taylor FG, Quirke P, Heald RJ, Moran B, Blomqvist L, Swift I, Sebag-Montefiore DJ, Tekkis P, Brown G. Preoperative high-resolution magnetic resonance imaging can identify good prognosis stage I, II, and III rectal cancer best managed by surgery alone: a prospective, multicenter, European study. Ann Surg. 2011; 253:711-719.

33. Beets-Tan RG, Beets GL, Vliegen RF, Kessels AG, Van Boven H, De Bruine A, von Meyenfeldt MF, Baeten CG, van Engelshoven JM. Accuracy of magnetic resonance imaging in prediction of tumour-free resection margin in rectal cancer surgery. Lancet. 2001; 357:497-504.

34. Engelen SM, Maas M, Lahaye MJ, Leijtens JW, van Berlo CL, Jansen RL, Breukink SO, Dejong CH, van de Velde CJ, Beets-Tan RG, Beets GL. Modern multidisciplinary treatment of rectal cancer based on staging with magnetic resonance imaging leads to excellent local control, but distant control remains a challenge. Eur J Cancer. 2013; 49:2311-2320.

35. Avallone A, Delrio P, Guida C, Tatangelo F, Petrillo A, Marone P, Cascini LG, Morrica B, Lastoria S, Parisi V, Budillon A, Comella P. Biweekly oxaliplatin, raltitrexed, 5-fluorouracil and folinic acid combination chemotherapy during preoperative radiation therapy for locally advanced rectal cancer: a phase I-II study. British Journal of Cancer. 2006; 94:1809-1815.

36. Mandard AM, Dalibard F, Mandard JC, Marnay J, Henry-Amar M, Petiot JF, Roussel A, Jacob JH, Segol P, Samama G, et al. Pathologic assessment of tumor regression after preoperative chemoradiotherapy of esophageal carcinoma. Clinicopathologic correlations. Cancer. 1994; 73:2680-2686.

37. Simon R. Optimal two-stage designs for phase II clinical trials. Control Clin Trials. 1989; 10:1-10.

38. Dische S, Saunders MI. Complexity and simplicity in the measurement and recording of the adverse effects of cancer treatment. Radiother Oncol. 2003; 66:249-251. 